\title{
Pemahaman Siswa SMP Perempuan Berkemampuan Rendah pada Masalah Kalimat Matematika
}

\author{
Enny Listiawati \\ STKIP PGRI BANGKALAN, ennylistiawati@stkippgri-bkl.ac.id
}

\begin{abstract}
ABSTRAK
Fokus masalah dalam penelitian ini adalah pemahaman siswa SMP pada masalah kalimat matematika karena hal ini sangat penting dan mempengaruhi kemampuan siswa dalam memecahkan masalah kalimat matematika. Adapun tujuan penelitan ini adalah untuk mendeskripsikan pemahaman siswa SMP perempuan dengan kemampuan matematika rendah pada masalah kalimat matematika. Subjek penelitian ini adalah satu orang siswa SMP perempuan kelas VIII yang mempunyai kemampuan matematika rendah. Instrumen penelitian ini adalah peneliti sendiri dengan instrumen pendukung yaitu soal tes kemampuan matematika, soal tes pemahaman pada kalimat matematika dan pedoman wawancara. Hasil penelitian yang diperoleh adalah bahwa pemahaman subjek perempuan pada masalah kalimat matematika yaitu pada komponen pemahaman interpreting subjek menginterpretasi masalah tersebut dengan menggunakan kalimat sendiri secara lengkap. Sedangkan pada komponen pemahaman summarizing subjek tidak menyatakan kalimat matematika dengan menggunakan notasi matematika akan tetapi dengan menggunakan kata-kata. Pada komponen pemahaman inferring subjek menyelesaikan masalah kalimat matematika secara terperinci dengan menggunakan perhitungan perkalian yang dituliskan secara lengkap dan subjek menyimpulkan jawaban sesuai dengan pertanyaan yang diajukan pada masalah kalimat matematika. Pada komponen pemahaman explaining subjek menjelaskan setiap langkah penyelesaiannya secara rinci serta menuliskannya pada hasil pekerjaanya.
\end{abstract}

Kata Kunci: Pemahaman, Masalah Kalimat Matematika, Kemampuan Tinggi

\begin{abstract}
The focus of the problem in this study is an understanding of junior high school students in mathemarical word problem because it is very important and affects the student's ability in solving mathematical problems sentences. The purpose of this research is to describe the understanding of female junior high school students with low mathematic competence in mathematical word problem. The subjects were a junior high students of class VIII women who have low mathematic competence. The instrument of this study is the researchers themselves with instruments that support mathematic competence test questions, test questions on sentence comprehension of mathematics and interview guidelines. The results obtained is that the understanding of the subject matter of women in mathematical word is on understanding components of interpreting the subject interpret these problems by using their own sentences in full. While on the subject summarizing understanding of the components do not declare the sentence mathematics using mathematical notation but by using words. On the subject component inferring understanding solve problems detailed mathematical sentence using the multiplication calculation is written in full and in accordance with the subject concludes answers to questions on the issue of mathematical sentence. In the component of understanding explaining the subject to explain each step of the solution in detail and write it on the results of his work.
\end{abstract}

Key words: Understanding, Mathematical word problem, High Competence 


\section{PENDAHULUAN}

Pemahaman siswa pada kalimat matematika merupakan hal penting yang tidak dapat diabaikan dalam pembelajaran matematika. Hal tersebut dikarenakan, dalam kehidupan seharihari banyak permasalahan yang harus diselesaikan secara matematika dimana penyelesaiannya memerlukan keterampilan memahami hubungan antara kalimat, bilangan dan simbol-simbol. Dengan mengetahui pemahaman siswa pada kalimat matematika, guru diharapkan dapat menentukan rencana pembelajaran yang tepat yang pada akhirnya akan dicapai hasil pembelajaran yang optimal.

Dalam penyelesaian masalah matematika, keberhasilan siswa sangat ditentukan oleh bagaimana siswa dapat membaca dan memahami kalimat pada masalah matematika tersebut. Menurut Pearce, Bruun, Skinner, \& Mohler [1], kesulitan siswa dalam memecahkan masalah kalimat matematika terjadi pada saat siswa membaca dan memahami permasalahan tersebut. Beberapa uraian di atas dapat diartikan bahwa ada keterkaitan antara membaca, kemampuan matematika dan pemahaman kalimat matematika. Siswa tidak mungkin dapat menyelesaikan masalah matematika jika siswa tersebut tidak mampu memahami kalimat matematika yang terkandung dalam masalah tersebut. Ada dua alasan mengapa pemahaman kalimat matematika sangatlah penting, yang pertama karena kalimat matematika adalah hal yang paling umum ditemukan pada sebagian besar soal matematika. Kedua,kemampuan untuk memecahkan masalah kalimat matematika adalah kemampuan dasar dan keterampilan kunci untuk memecahkan masalah matematika.

Berdasarkan penelitian yang dilakukan oleh Gooding [2] di Inggris menyatakan bahwa kesulitan yang paling banyak dialami siswa dalam masalah matematika adalah membaca dan memahami bahasa yang digunakan dalam suatu masalah serta siswa tidak mampu memahami konteks permasalahan yang ada. Strategi yang paling banyak digunakan oleh guru adalah mendorong siswa untuk membaca permasalahan secara menyeluruh, serta guru membantu siswa memberikan informasi dalam masalah matematika. Sedangkan Seifi \& et all [3] melakukan penelitian di Irak menyebutkan bahwa mayoritas siswa mengalami kesulitan dalam memecahkan masalah kalimat matematika karena siswa kesulitan dalam merepresentasikan dan memahami masalah. Strategi yang paling sering digunakan guru untuk membantu kesulitan siswa adalah mengidentifikasi kata kunci pada teks dengan cara melingkari, menggarisbawahi atau mewarnai informasi pada teks.

Hal ini diperkuat oleh penelitian Langeness [4] di Minnesota, Amerika Serikat mengatakan bahwa siswa yang menuliskan permasalahan dengan kalimat mereka sendiri dapat meningkatkan kemampuan dalam memahami dan memecahkan masalah kalimat matematika. Dari uraian beberapa hasil penelitian tersebut maka pemahaman siswa pada masalah kalimat matematika sangat diperlukan agar siswa tidak mengalami kesulitan dalam memecahkan masalah kalimat matematika.

Penulis menduga adanya perbedaan pemahaman siswa dalam memecahkan masalah kalimat matematika berdasarkan gender. Hal ini sesuai dengan penelitian yang dilakukan oleh Maccoby dan Jacklin dalam Hadiyan [5] bahwa ada perbedaan antara anak laki-laki dan perempuan dalam kemampuan berpikir. Anak laki-laki pada umumnya memiliki kemampuan lebih unggul dalam kemampuan visual spasial dan penalaran logis. Sedangkan anak perempuan lebih unggul dalam kemampuan verbal. Dengan demikian ada kecenderungan perbedaan pemahamanan siswa laki-laki dan perempuan pada masalah kalimat matematika. Hal ini diperkuat dengan penelitian yang dilakukan oleh $\mathrm{Zu}$ [6] di Adelaide, Australia Selatan bahwa ada perbedaan antara laki - laki dan perempuan dalam memecahkan masalah matematika. Hal ini dipengaruhi oleh kemampuan, psikologis, pengalaman dan pendidikan siswa.

Menurut Gallagher [7] perbedaan gender memiliki peran dalam pola-pola kesuksesan dan penggunaan strategi dalam pemecahan masalah konvensional dan non konvensional atau modern. Secara spesifik Gallagher [7] menyatakan bahwa siswa perempuan lebih sukses 
daripada siswa laki-laki untuk memecahkan masalah konvensional dengan menggunakan strategi algoritma, sedangkan siswa laki-laki lebih sukses daripada siswa perempuan untuk memecahkan masalah non konvensional atau modern dengan menggunakan estimasi logis atau wawasan. Sedangkan Pajares [8] menjelaskan bahwa siswa perempuan lebih baik daripada siswa laki-laki dalam memecahkan masalah matematika.

Berdasarkan uraian tersebut maka tujuan penelititan ini adalah untuk mendeskripsikan pemahaman siswa SMP laki-laki dan perempuan pada masalah kalimat matematika.

\subsection{Pemahaman}

Pemahaman merupakan hasil dari aktivitas mental individu itu dalam memahami konsep. Seseorang memahami suatu konsep karena telah melakukan aktivitas berpikir tentang konsep tersebut. Sementara itu, menurut Driver (Jafar) [9] pemahaman adalah kemampuan menjelaskan suatu situasi atau suatu tindakan. Dari hal ini, pemahaman mengandung tiga komponen penting. Pertama, berkaitan dengan kemampuan mengenali atau mengidentifikasi unsur-unsur yang membangun obyek, situasi atau tindakan yang dimaksud. Kedua, berkenaan dengan kemampuan menjelaskan sifat-sifat esensial sebagai batasan dari obyek, situasi atau tindakan dimaksud, dan ketiga berkenaan dengan kemampuan menginterpretasi .

Menurut Minggi [10] pemahaman adalah pengkaitan antara skema yang ada dengan informasi yang diterima. Siswa dikatakan memiliki pemahaman terhadap masalah kalimat matematika jika siswa tersebut telah mampu memahami arti, situasi serta fakta yang diketahui dan mampu mengaitkan konsep-konsep yang baru diterima dengan konsep-konsep yang telah dimiliki sebelumnya. Didukung oleh pendapat Rohana [11] yang menyatakan bahwa siswa dikatakan memahami konsep yang diberikan dalam pembelajaran jika mereka mampu mengemukakan dan menjelaskan suatu konsep yang diperolehnya berdasarkan kata-kata sendiri tidak sekedar menghafal.

Asdar [12] menyimpulkan bahwa pemahaman adalah pengetahuan seseorang tentang suatu konsep yang dapat diungkap melalui kemampuannya menginterpretasikan, menghitung, mengklasifikasikan, menalar, membandingkan, membuktikan, dan menjelaskan baik secara lisan maupun tertulis ketika menyelesaikan suatu masalah. Pemahaman seorang individu terhadap suatu konsep merupakan hasil dari aktivitas mental individu itu dalam memahami konsep yang dimaksud. Seseorang memahami sesuatu konsep karena telah melakukan aktivitas berpikir tentang konsep tersebut. Skemp [13] berpendapat bahwa "to understand something means to assimilate it into an appropriate schema". Hal ini mengandung arti bahwa seseorang dikatakan memahami sesuatu apabila telah terjadi pengintegrasian informasi baru dengan skema yang dimiliki orang tersebut. Dari sini dapat dikatakan bahwa pemahaman berkaitan dengan kemampuan (ability) seseorang dalam pengintegrasian informasi baru melalui proses akomodasi dan asimilasi kedalam skema yang dimiliki orang tersebut sebelumnya sehingga terbentuk skema baru.

Pemahaman menurut Kilpatrick dan Findell [14] adalah pemahaman yang terintegrasi dan fungsional dari ide-ide matematika. Seseorang yang memiliki pemahaman konsep telah mengorganisir pengetahuan mereka kedalam satu kesatuan yang utuh yang memungkinkan untuk belajar ide-ide baru dengan menghubungkan ide-ide yang telah ada sebelumnya. Pemahaman konsep akan membuat bertahan lama karena fakta dan metode belajar dengan pemahaman yag terhubung, maka akan memudahkan untuk mengingat dan menggunakan kembali serta dapat direkontruksi ketika sudah lupa. Siswa yang mempunyai pemahaman konsep akan dapat menjelaskan kembali konsep dengan bahasa sendiri. Adapun indikator pemahaman konsep menurut Kilpatrick dan Findell [14] adalah mampu merepresentasikan konsep matematika dengan cara yang berbeda dan mengetahui cara merepresentasikannya dengan tujuan yang berbeda 
Sedangkan menurut Krathwohl,dkk [15] ada tujuh proses kognitif pemahaman yang meliputi: (1) Interpreting (menginterpretasikan atau menafsirkan) artinya mengubah informasi dari suatu representasi ke representasi yang lain misalnya menafsirkan sesuatu dengan katakata sendiri, menafsirkan gambar dengan kata-kata atau sebaliknya, menafsirkan bilanganbilangan dengan kata-kata dan sebaliknya. (2) Exemplifying (memberikan contoh) artinya memberikan contoh spesifik dari suatu konsep atau prinsip. (3) Classifying (mengklasifikasikan) artinya mengklasifikasikan sesuatu atau contoh-contoh yang merupakan kategori konsep atau prinsip. (4) Summarizing (meringkas) artinya memberikan pernyataan tunggal yang mewakili informasi yang disajikan atau abstrak dari sebuah tema umum. (5) Inferring (menyimpulkan) yaitu menarik kesimpulan logis dari informasi yang disajikan. (6) Comparing (membandingkan) adalah mendeteksi kesamaan dan perbedaan antara dua atau lebih objek, kejadian, ide, masalah, situasi. (7) Explaining (menjelaskan) adalah mengkonstruksikan dan menggunakan sebab dan akibat model sebuah sistem.

Dalam penelitian ini yang dimaksud pemahaman adalah pengintegrasian skema yang ada pada siswa dengan informasi yang diterimanya pada masalah kalimat matematika berdasarkan proses kognitif pemahamanan menurut Krathwoll [15].

\subsection{Masalah Kalimat Matematika}

Cummins (Seifi \& et all) [3] mengatakan bahwa masalah kalimat matematika didefinisikan sebagai deskripsi verbal dari situasi masalah dimana terdapat satu atau lebih pertanyaan yang diangkat serta jawabannya dapat diperoleh dengan penerapan operasi matematika untuk data numerik yang tersedia dalam pernyataan masalah. Masalah kalimat matematika sebagian besar mengaitkan situasi dunia nyata untuk konsep-konsep matematika. Bahkan, masalah tersebut membantu siswa untuk menggunakan pengetahuan matematika mereka dalam memecahkan masalah sehari-hari. Menurut De Coete dkk (Seifi \& et all) [3] masalah kalimat matematika dikenal sebagai instrumen yang mengembangkan kemampuan siswa dan bakat dalam memecahkan masalah matematika.

Menurut Charles [16] masalah kalimat matematika adalah suatu konteks dunia nyata dimana secara matematis diberikan satu atau lebih kuantitas nilai - nilai yang diketahui, diberikan satu atau lebih kuantitas nilai - nilai yang tidak diketahui, hubungan antara kuantitas nilai - nilai yang diuraikan, suatu pertanyaan dimulai dengan menemukan nilai dari kuantitas yang tidak diketahui dan satu atau lebih operasi penjumlahan, pengurangan, perkalian, dan pembagian dapat digunakan untuk menemukan nilai yang ditanyakan tersebut. Selanjutnya Pearce [1] mengatakan bahwa masalah kalimat matematika adalah gabungan antara kalimat, bilangan, huruf, simbol, dan grafik. Masalah ini juga dikenal sebagaimasalaharitmatikalisan, masalahcerita, masalah kata, dan pemecahan masalahsituasi dapat membantusiswa untuk membacadan memahami masalah kalimat matematika.

Barwell (Langeness) [4] mengatakan bahwa masalah kalimat matematika memiliki struktur tiga bagian, yaitu (1) "set up " untuk menjelaskan skenario masalah, (2) sejumlah informasi tentang situasi itu, (3) akhirnya / beberapa pertanyaan pada akhir. Hal ini dapat dilihat pada masalah berikut :'Dua bilangan berselisih 25. Jika 2 kali bilangan yang besar dikurangi bilangan yang kecil adalah 175. Tentukanlah kedua bilangan itu”. Siswa harus membaca berulang - ulang untuk memahami makna dari masalah tersebut. Matematika menggunakan kosakata yang sangat spesifik dan khusus . Kata-kata seperti penyebut, segiempat, jajaran genjang, dan sama kaki adalah istilah khusus hanya ditemukan dalam konteks matematika ( Rubenstein \& Thompson dalam Langeness, [4]). Dalam pembagian, istilah pembagi dan hasil bagi harus dipelajari agar siswa tidak mengalami kesulitan. Ungkapan "dibagi” berbeda makna dengan "membagi". Sebagai contoh , 6 dibagi 12 adalah 0,5 , sedangkan 6 membagi 12 adalah 2 . 
Berdasarkan uraian diatas, maka dalam penelitian ini yang dimaksud dengan masalah kalimat matematika adalah masalah matematika yang berupa gabungan antara kalimat, bilangan, huruf, simbol baik yang merupakan konteks dunia nyata maupun tidak.

\subsection{Pemahaman Pada Masalah Kalimat Matematika}

Indikator pemahaman pada masalah kalimat matematika pada penelitian ini mengacu pada proses kognitif pemahaman menurut Krathwohl,dkk [15] yang disesuaikan dengan kebutuhan penelitian disajikan pada tabel 1 berikut:

Tabel 1 Pemahaman Pada Masalah Kalimat Matematika

\begin{tabular}{|c|l|l|}
\hline No & \multicolumn{1}{|c|}{$\begin{array}{c}\text { Komponen Pemahaman Pada } \\
\text { Masalah Kalimat Matematika }\end{array}$} & \multicolumn{1}{c|}{ Indikator } \\
\hline 1 & $\begin{array}{l}\text { Interpreting (Menginterpretasikan atau } \\
\text { menafsirkan) }\end{array}$ & $\begin{array}{l}\text { Menginterpretasi kalimat matematika dalam kata-kata } \\
\text { sendiri, bilangan dan simbol matematika }\end{array}$ \\
\hline 2 & Summarizing (Meringkas) & $\begin{array}{l}\text { Meringkas masalah kalimat matematika dengan } \\
\text { membuat notasi matematikanya }\end{array}$ \\
\hline 3 & Inferring (Menyimpulkan) & $\begin{array}{l}\text { Mencari solusi dan menyimpulkan masalah kalimat } \\
\text { matematika }\end{array}$ \\
\hline 4 & Explaining (Menjelaskan) & $\begin{array}{l}\text { Menjelaskan setiap langkah penyelesaian masalah } \\
\text { kalimat matematika secara logis dan terperinci }\end{array}$ \\
\hline
\end{tabular}

\subsection{Hasil Penelitian Yang Relevan}

Beberapa penelitian-penelitian yang berkaitan dengan pemahaman siswa pada masalah kalimat matematika ditinjau dari gender dan kemampuan matematika antara lain :

1. Hasil penelitian Pearce dkk [1] di Amerika menyimpulkan bahwa kesulitan yang paling sering dialami siswa dalam masalah kalimat matematika adalah kemampuan membaca dan memahami masalah. Penyebab dari kesulitan tersebut adalah kesulitan teks, guru sebelumnya serta faktor dari siswa itu sendiri. Sedangkan strategi yang paling sering digunakan oleh guru dalam membantu siswa untuk memecahkan masalah kata adalah mengidentifikasi kata kunci dalam teks.

2. Hasil penelitian Seifi [3] di Irak menyebutkan bahwa mayoritas siswa mengalami kesulitan dalam memecahkan masalah kalimat matematika karena siswa kesulitan dalam merepresentasikan dan memahami masalah. Penyebab kesulitan siswa adalah kesulitan teks. Strategi yang paling sering digunakan guru untuk membantu kesulitan siswa adalah mengidentifikasi kata kunci pada teks dengan cara melingkari, menggarisbawahi atau mewarnai informasi pada teks.

3. Hasil penelitian Langeness [4] di Minnesota, Amerika Serikat mengatakan bahwa siswa yang menuliskan permasalahan dengan kalimat mereka sendiri dapat meningkatkan kemampuan dalam memahami dan memecahkan permasalahan kalimat matematika.

4. Hasil penelitian oleh $\mathrm{Zu}$ [6] di Adelaide, Australia Selatan adalah bahwa ada perbedaan antara laki - laki dan perempuan dalam memecahkan masalah matematika. Hal ini dipengaruhi oleh kemampuan, psikologis, pengalaman dan pendidikan siswa.

\section{Metode}

Jenis penelitian ini adalah deskriptif-kualitatif dengan fokus penelitian adalah deskripsi pemahaman siswa SMP perempuan dengan kemampuan matematika rendah pada masalah kalimat matematika. Subjek penelitian ini adalah satu siswa perempuan SMP kelas VIII di SMPN 5 Bangkalan yang mempunyai kemampuan matematika rendah. 
Instrumen utama penelitian adalah peneliti sendiri dan instrumen pendukung: (1) soal Tes Kemampuan Matematika (TKM) yang terdiri dari 10 butir soal tes yang mengadopsi soal-soal UNAS dan mengambil materi yang sudah pernah dipelajai oleh siswa. Tujuan dari pemberian soal Tes Kemampuan Matematika ini adalah untuk menentukan subjek penelitin yaitu satu siswa perempuan yang memiliki kemampuan matematika rendah, (2) soal Tes Pemahaman pada masalah kalimat matematika yang terdiri dari dua soal uraian pada materi bilangan bulat. Tujuannya adalah untuk menggali dan mengeksplorasi pemahaman siswa pada masalah kalimat matematika, dan (3) pedoman wawancara yang berisi garis besar pertanyaan kepada responden.

Secara garis besar, prosedur penelitian yang digunakan oleh peneliti terdiri dari empat tahap, yaitu: tahap perencanaan, tahap pelaksanaan, tahap analisis data, dan pembuatan laporan.

1. Tahap Perencanaan

Pada tahap ini, kegiatan yang dilakukan adalah merancang instrumen penelitian yang meliputi tes kemampuan matematika, tes pemahaman pada masalah kalimat matematika dan pedoman wawancara.

2. Tahap Pelaksanaan

Pada tahap ini, kegiatan yang dilakukan adalah:

a. Menentukan subjek penelitian berdasarkan hasil tes kemampuan matematika dan gender. Siswa dikelompokkan menjadi tiga, yaitu siswa berkemampuan rendah, siswa berkemampuan sedang, siswa berkemampuan tinggi. Kemudian memilih satu siswa perempuan dari kelompok rendah.

b. Memberikan Tes Pemahaman pada masalah kalimat matematika kepada subjek penelitian.

c. Melakukan wawancara pada subjek penelitian agar peneliti mendapatkan informasi mengenai pemahaman siswa pada masalah kalimat matematika sebagai bahan untuk menarik kesimpulan..

3. Tahap Analisis Data

Pada tahap ini, kegiatan yang dilakukan adalah:

a. Mereduksi data, untuk menajamkan informasi, menggolongkan dan membuang yang tidak perlu serta mengorganisasikan data mentah yang diperoleh pada saat melakukan pengumpulan data.

b. Memaparkan data yang diperoleh dari tahap pelaksanaan yaitu hasil pekerjaan siswa pada masalah kalimat matematika yang dicapai sesuai dengan metode analisis data yang telah ditentukan.

c. Mendeskripsikan hasil analisis data

4. Tahap Pembuatan Laporan

Pada tahap ini, peneliti membuat laporan hasil penelitian mengenai pemahaman siswa perempuan pada masalah kalimat matematika.

\section{Hasil dan Pembahasan}

Data yang diperoleh dari hasil pekerjaan siswa dan hasil wawancara kemudian dianalisis. Berikut ini adalah contoh masalah kalimat matematika yang digunakan peneliti, yaitu:

Dalam suatu ulangan dengan 45 buah soal, setiap jawaban benar diberi nilai 5 dan jawaban salah diberi nilai 3 dan tidak menjawab diberi nilai 0 (nol). Giovani menjawab benar sejumlah 33 soal, menjawab salah sejumlah 4 soal dan sisanya tidak dijawab. Berapa nilai yang diperoleh Giovani?

Hasil pekerjaan siswa perempuan ditunjukkan pada gambar 1 di bawah ini: 


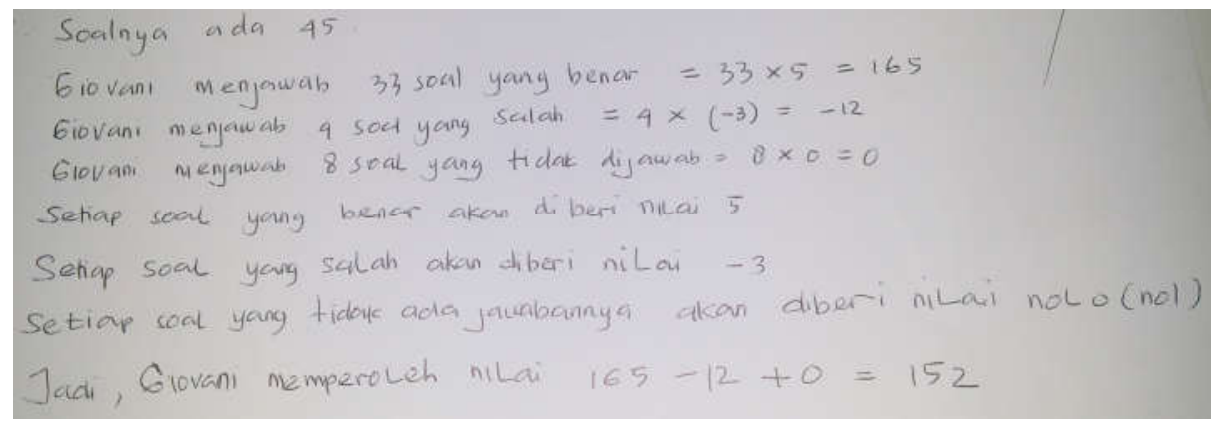

Gambar 1 Hasil Pekerjaan Subjek

Berdasarkan hasil wawancara yang dilakukan oleh peneliti dengan subjek perempuan diperoleh informasi mengenai pemahaman subjek pada masalah kalimat matematika yaitu pada komponen pemahaman interpreting subjek menginterpretasi masalah tersebut dengan menggunakan kalimat sendiri secara lengkap hal ini bisa ditunjukkan oleh transkrip wawancara berikut ini:

Peneliti : Coba kamu jelaskan maksud dari soal ini!

Subjek: Soalnya ada 45. Giovani menjawab 33 soal yang benar. Soal benar nilainya 5. Terus dia menjawan 4 soal yang salah. Soal salah nilainya -3 . Soal yang tidak dijawab nilainya 0 . Yang ditanyakan adalah nilai yang diperoleh Giovani!

Sedangkan pada komponen pemahaman summarizing subjek tidak menyatakan kalimat matematika dengan menggunakan notasi matematika akan tetapi dengan menggunakan katakata, hal ini ditunjukkan oleh transkrip wawancara berikut:

Peneliti : Coba kamu tulis soal yang tadi dengan menggunakan simbol atau lambang!

Subjek: Saya tidak tahu bu, saya pakai kalimat

Pada komponen pemahaman inferring subjek menyelesaikan masalah kalimat matematika secara terperinci dengan menggunakan perhitungan perkalian yang dituliskan secara lengkap dan subjek menyimpulkan jawaban sesuai dengan pertanyaan yang diajukan pada masalah kalimat matematika. Hal ini dapat dilihat pada trasnkrip wawancara berikut ini:

Peneliti : Bagaimana cara kamu menyelesaikannya?

Subjek: Soal yang benar 33 dikali 5 hasilnya 165. Soal yang salah 4 dikali -3 nilainya -12 . Soal yang tidak dijawab 8 dikali 0 nilainya 0 . Kemudian saya jumlahkan 165$12+0$ nilainya 153. Jadi nilai yang diperoleh Giovani adalah 153 .

Pada komponen pemahaman explaining subjek menjelaskan setiap langkah penyelesaiannya secara rinci serta menuliskannya pada hasil pekerjaanya.

Berdasarkan hasil analisis data tersebut diperoleh data pemahaman siswa perempuan pada masalah kalimat matematika yaitu pada komponen pemahaman interpreting subjek menginterpretasikan masalah yang diberikan dengan kalimat sendiri dan dinyatakannya secara lengkap. Hal ini sesuai dengan penelitian yang dilakukan oleh Maccoby dan Jacklin dalam Hadiyan [5] yang menyebutkan bahwa perempuan lebih unggul dalam segi verbal sedangkan laki-laki lebih unggul dalam segi visual spasial. Hal ini juga sesuai dengan hasil penelitian Langeness [4] di Minnesota, Amerika Serikat mengatakan bahwa siswa yang menuliskan permasalahan dengan kalimat mereka sendiri dapat meningkatkan kemampuan dalam memahami dan memecahkan permasalahan kalimat matematika. 
Pada komponen pemahaman summarizing subjek perempuan tidak menyatakan masalah kalimat matematika tersebut dengan menggunakan notasi matematika akan tetapi dengan menggunakan kata-kata.

Pada komponen pemahaman inferring ditemukan subjek perempuan menyelesaikan masalah kalimat matematika dengan menggunakan aturan perkalian dan penjumlahan serta menuliskan caranya secara rinci. Hal ini sesuai dengan penelitian yang dilakukan oleh Pajares [8] yang menyatakan bahwa siswa perempuan lebih baik daripada siswa laki-laki dalam memecahkan masalah matematika. Subjek juga menyimpulkan jawaban yang diperoleh sesuai dengan pertanyaan pada soal.

Pada komponen pemahaman explaining subjek perempuan menjelaskan setiap langkah yang dilakukan untuk menyelesaikan masalah secara logis dan terperinci.

\section{Penutup}

Berdasarkan analisis hasil penelitian maka dapat disimpulkan bahwa pemahaman subjek perempuan pada masalah kalimat matematika yaitu pada komponen pemahaman interpreting subjek menginterpretasi masalah tersebut dengan menggunakan kalimat sendiri secara lengkap. Sedangkan pada komponen pemahaman summarizing subjek tidak menyatakan kalimat matematika dengan menggunakan notasi matematika akan tetapi dengan menggunakan katakata. Pada komponen pemahaman inferring subjek menyelesaikan masalah kalimat matematika secara terperinci dengan menggunakan perhitungan perkalian yang dituliskan secara lengkap dan subjek menyimpulkan jawaban sesuai dengan pertanyaan yang diajukan pada masalah kalimat matematika. Pada komponen pemahaman explaining subjek menjelaskan setiap langkah penyelesaiannya secara rinci serta menuliskannya pada hasil pekerjaanya.

\section{Ucapan Terima Kasih}

Penulis mengucapkan terima kasih kepada:

1. Pihak SMPN 5 Bangkalan yang telah memberikan kesempatan bagi peneliti untuk melakukan penelitian.

2. Prodi Studi Pendidikan Matematika STKIP PGRI Bangkalan

3. Pihak-pihak terkait yang telah banyak membantu terselesaikannya penelitian ini.

\section{DAFTAR PUSTAKA}

[1] Pearce, D. L., Bruun, F., Skinner, K., \& Mohler, C. L. (2013). What Teachers Say About Student Difficulties Solving Mathematical Word Problem in Grade 2-5. International Electronic Journal of Mathematic Education Vol 8 No. 1, 3-19.

[2] Gooding, S. (2009). Children's Difficulties With Mathematical Word Problem. Proceedings of The British Society For Research Into Learning Mathematics.

[3] Seifi, M., \& et all. (2012). Recognition Of Student's Difficulties In Solving Mathematical Word Problems From The Viewpoint Of Teachers. Journal Of Basic and Applied Scientific Research.

[4] Langeness, J. (2011). Methods To Improve Student Ability In Solving Mathematics Word Problems. Dipetik September 24, 2013, dari www.hamline.co.iy 
[5] Hadiyan, A. (2007). Penelusuran Tingkat Berpikir Geomteri Siswa Laki-laki dan Perempuan SMPN 1 Karksanan Probolinggo Berdasarkan Teori Van Hiele. Surabaya: PPs UNESA TESIS.

[6] Zu, Z. (2007). Gender Differences In Mathematical problem Solving Patterns : A Review Of Literarture. International Education Journal 8(2), 187-203.

[7] Gallagher, A. M. (2000). Gender Differences In Advaced Mathematical Problem Solving and Arithmetical Reasoning. Journal of Experimental Child Psychology 75, 165-190.

[8] Pajares,F. (1996). Self-Efficacy Beliefs and Mathematical Word Problem Solving of Gifted Student. Contemporary Educational Psychology, 21, 325-344

[9] Jafar. (2013). Membangun Pemahaman Yang Lengkap (Completely Understanding) Dalam Pembelajaran Konsep Grup. KNPM V Himpunan Matematika Indonesia.

[10] Minggi, I. (2010). Proses Intuisi Mahasiswa Dalam Memahami Konsep Limit Fungsi Berdasarkan Perbedaan Gender.Disertasi. Surabaya: Universitas Negeri Surabaya.

[11] Rohana. (2011). Pengaruh Pembelajaran Berbasis Masalah Terhadap Pemahaman Konsep Mahasiswa Prodi Pendidikan Matematika FKIP Universitas PGRI Palembang. Prosiding Seminar Pendidikan Matematika Universitas PGRI Palembang Pada Tanggal 27 Juni 2011.

[12] Asdar. (2012). Profil Konflik Kognitif Mahasiswa Dalam Pemahaman Ditinjau Dari Perbedaan Kemampuan Kalkulus. Disertasi. Surabaya: Universitas Negeri Surabaya.

[13] Skemp, R. (1976). Relational Understanding Mathematic Teaching. 77, 20-26. Dipetik Oktober 23, 2014, dari http://www.grahamtall.co.uk/skemp/pdfs/instrumentalrelational.pdf.

[14] Kilpatrick, J., \& Findell, B. (2001). Adding It Up : Helping Children Learn Matematics. Diambil kembali dari http://www.nap.edu/catalog/9822.html

[15] Krathwohl, D. R., \& Anderson, L. W. (2001). A Taxonomy For Learning, Teaching and Assessing: A Revision Of Blooms Taxonomy Of Educational Objectives. New York: Longman.

[16] Charles, R. (1987). Solving Word Problems. Research Into Pretice Mathematics. Pearson Education Inc. 